\title{
Nerve Regeneration in Vein Grafts Seeded with Adult Schwann Cells
}

\author{
Hamid Reza Fathi ${ }^{1}$, Mohammad Mirabdullah Davudov ${ }^{2 *}$, Mina Tabrizi ${ }^{3}$, Parisa Foroughiasl ${ }^{2}$, Rashad Mammadzadeh ${ }^{2}$ and Sanan Khankishiyev ${ }^{2}$ \\ ${ }^{1}$ Department of Plastic, Reconstructive and Aesthetic Surgery, Tehran University of Medical Sciences, Tehran, Iran \\ ${ }^{2}$ Department of Oral and Maxillofacial Surgery. Azerbaijan Medical University, Azerbaijan \\ ${ }^{3}$ Medical Genetics Department, Tehran University of Medical Sciences, Tehran, Iran
}

"Corresponding author: Mohammad Mirabdullah Davudov, Department of Oral and Maxillofacial Surgery. Azerbaijan Medical University, Azerbaijan, E-mail: mahammad_davud@mail.ru

Received: 04 Apr, 2018 | Accepted: 10 Oct, 2018 | Published: 18 Oct, 2018

Citation: Fathi HR, Davudov MM, Tabrizi M, Foroughiasl P, Mammadzadeh R, et al. (2018) Nerve Regeneration in Vein Grafts Seeded with Adult Schwann Cells. Cell Stem Cells Regen Med 3(2): dx.doi.org/10.16966/2472-6990.120

Copyright: ( 2018 Fathi HR, et al. This is an open-access article distributed under the terms of the Creative Commons Attribution License, which permits unrestricted use, distribution, and reproduction in any medium, provided the original author and source are credited.

\section{Abstract}

Background: Using grafts in order to facilitate peripheral nerve regeneration, it is important to consider immune system stimulation, flexibility and strain bearing. Success is mainly due to Schwann cells, growth factors and the extracellular matrix. Since endogenous Schwann cells are not sufficient, exogenously cultured cells play an essential role in axonal regeneration, especially in peripheral locations.

Methods: Two grafting techniques were compared including venous grafts with and without Schwann cells in rats during a 4-month period of time.

Results: Grafts containing Schwann cells showed 8-times greater motion power compared to the control group.

Conclusion: It seems Schwann cells play a crucial role in axonal regeneration and repair in the peripheral nervous system.

Keywords: Nerve regeneration; Venous graft; Schwann cells

\section{Introduction}

In cases where a nerve is cut, a nerve graft sometimes maybe essential in the gap between the proximal and the distal part of a nerve. Recent two decades have witnessed two types of grafts to fill the gap with natural and synthetic groups. Natural grafts usually include peripheral nerves, artery, vein or even muscle autografts, allografts and xenografts with certain limitations. Synthetic grafts, namely polyglycolic acid (PGA), polylactic acid or polylactide (PLA), polylactic-coglycolic acid (PLGA) and polyhydroxyalkanoate (PHA) are usually useful when general and specific situations limit the use of natural grafts [1-4]. Many experiments have shown scarcity of endogenous Schwann cell numbers which is a risk factor to imperfect regeneration. Thus, exogenous cultured cells have become important. Carriel, et al. were one of several groups to use histology, tissue chemistry, immunochemistry and ultrastructural techniques for axonal regeneration in the peripheral nervous system (PNS) [1]. To better decipher the role Schwann cells play in nerve regeneration, it was discovered that Schwann cells change the naked peripheral axons into myelinated fibers via folding several times around them to make myelin while Schwann cells only surround fine axons to cover them without myelinating them. The first steps toward better repair and regeneration in the PNS is by achieving cell infiltration in the damaged site and Schwann cells are essential aside from the needed trophic factors. Extracellular matrix is generated by cell infiltration which plays a crucial role in providing Bungner's bands. Bungner's bands provide leading bridges to help axons reach the distal side of the damaged area where there is a gap to shorten the trip from the proximal to the distal $[1,5]$ ends. This is the cornerstone of axonal regrowth and nerve repair since the distal part of the damage would decay and regeneration can only be accomplished by the only living side. Some studies argue that PNS damage in mammals causes nerve demyelination and, at the same time, increases expression of transcription factors which ultimately result in Schwann cells move into proximity of undifferentiated cells [6]. The resulting immature cells, in turn, start making columnar structures named Bungner's bands [6-8]. The molecular basis of nerve regeneration has been the focus of many investigators $[6,9]$ and some believe that nervous function cannot be exactly restored since some fine skills are lost and would only return by physical activities and exercise [10]. A group of researchers, in 2013, reported grafting peripheral nerves with Schwann cells and bone marrow stromal cells. Both cell lines have the potential of producing neural growth factors (NGFs), brain-derived neural growth factor (BDNF) and vascular endothelial growth factor (VEGF) [11]. Zarbakhsh, et al. demonstrated Schwann cell (SC) superior performance in nerve repair and regeneration [11]. This is while some studies have shown that SCs are not enough in axonal regeneration and some other cells like parenchymal stem cells would 
essentially lead the process by producing special neurotrophic factors. The current study was designed to introduce a functional mechanical support for SCs in peripheral nerve repair and confirm SC contribution to nerve regeneration in a new experimental setting [12-15].

\section{Materials and Methods}

Two types of venous grafts were compared to better understand the role of Schwann cells in axonal repair and regeneration in the PNS. This study used "vistar rats" to test performance of their sciatic nerves.

\section{Preparation of Schwann cells}

Previous studies on SCs used the PASS software. The sample size was determined to be 5 for each group with intervention. Thus, 10 rats were kept for 2 weeks in scheduled 12-hour periods of day and night-like situation in addition to provisions for suitable ventilation and nutrition before dividing them into two 5-member groups for intervention. Two centimeters of the sciatic nerve was cut into $1-2 \mathrm{~mm}$ segments after epineurium removal. To induce valerian's degeneration, nerve segments were placed in the D-10 medium for 14 days before placement in DMEM medium which contained 1,300 international units (IU) of collagenase per $\mathrm{ml}$ in addition to $10 \mathrm{IU}$ of dispase per $\mathrm{ml}$. To isolate SCs, cell cultures were established after evaluating the medium for cell viability and cell count in 24-well plates covered by collagen. We used Forskolin $(0.8 \mu \mathrm{g} / \mathrm{ml})$ and Heregulin $(2.5 \mathrm{~nm})$ to obtain more cells in culture.

\section{Preparation of vein grafts}

To provide suitable vein grafts, $2.5 \mathrm{~cm}$ of femoral vein was excised after opening the site and the local muscle as well as the local fascia. The grafts were placed in at $4^{\circ} \mathrm{C}$ before being placed at the damaged site instead of the neural growth canal.

\section{Transplantation of Schwann cells}

Cultured Schwann cells were injected into the grafts in group number two immediately after the process of grafting provided the vein. We used $0.5 \mathrm{cc}$ of cell suspension for each graft which contained half a million cells. The cells used had been placed in BrdU culture medium 24 hours before transplantation and 6 weeks after the process. The graft and the proximal and distal ends of the damaged nerve were evaluated with anti-BrdU antibody and anti-S100 antibody to define the qualitative and quantitative condition of regeneration. The ToluidineBlue color technique was used to study the axons. Neurological assessment was done 4 months later with electromyography (EMG) and behavioral tests.

\section{Statistics}

To find any significance between the two study groups, SPSS21 for windows was used to conduct the t-test and the chi-square test considering $95 \% \mathrm{CI}$ and 0.05 type 1 error.

\section{Outcome measures}

Two prominent variables were the focus including the amplitude of neural stimulation and its latency. The amplitude of neural stimulation is indicative of the capability of the graft to transfer the stimulation from the proximal to the distal end while latency means the spent time to transfer the signal between the two sides. The amplitude shows the density of axons after transplantation, and the EMG demonstrates higher amplitude in case of more nerve fiber density. Latency represents nerve function by showing live axons at the site of the graft. The harmony of the nerve fibers and their myelination rate would also affect latency. Lower latency rate means faster stimulation transfer.

\section{Results}

As can be seem in figures 1 and 2, the amplitude of the transferred signals were lower than $10 \mathrm{mv}$ in all the rats which were grafted with cell-free veins. This is while the amplitude approached just lower than $45 \mathrm{mv}$ in the SC-containing grafted group of rats. Figure 3 shows the mean amplitudes of the two groups which significantly differ. These findings suggest an $8 \mathrm{X}$ higher amplitude of the signal in the group with the Schwann-cell containing vein grafts compared to the control group after 6 weeks.

Regarding latency, a difference was seen between the two methods of intervention although not significant. Figure 4 indicates that all but

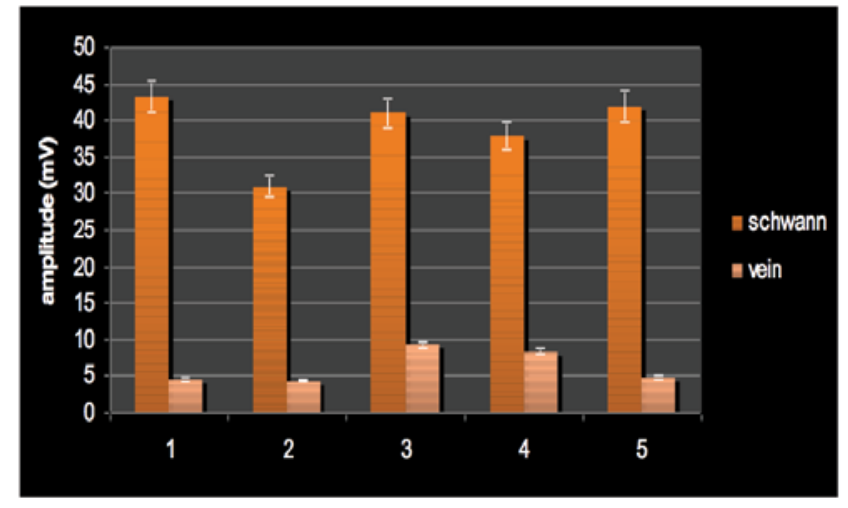

Figure 1: The amplitude in the two groups showing individual data for each rat in its respective group.

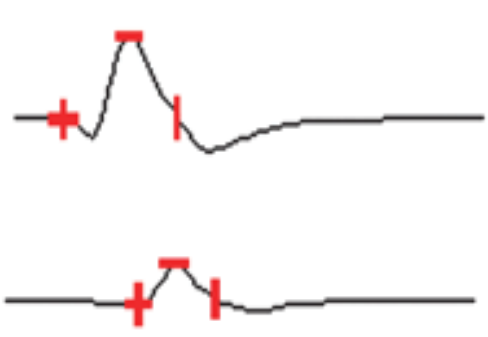

Figure 2: The graph showing amplitude means in the two groups.

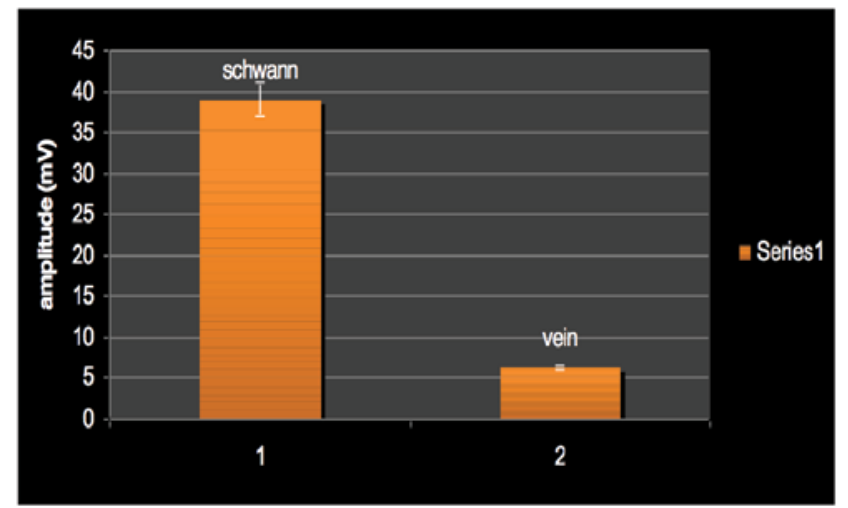

Figure 3: Means of amplitude in the two groups. 
two rats in group 1 and all but one of the rats in group 2 had latency rate in the range of 1.5-2 ms. Regarding the means, the Schwann cellcontaining graft showed more latency compared to the control group but no significance was found ( $2 \mathrm{~ms} v s .1 .7 \mathrm{~ms}$ ). Figure 5 compares the means of latency through the groups.

\section{Pathology}

Pathological studies of distal cuts of the sciatic nerve were studied after six weeks to evaluate the quality and quantity of axonal regrowth which is presented in figure 6 . There was no comparison between the groups in this regard.

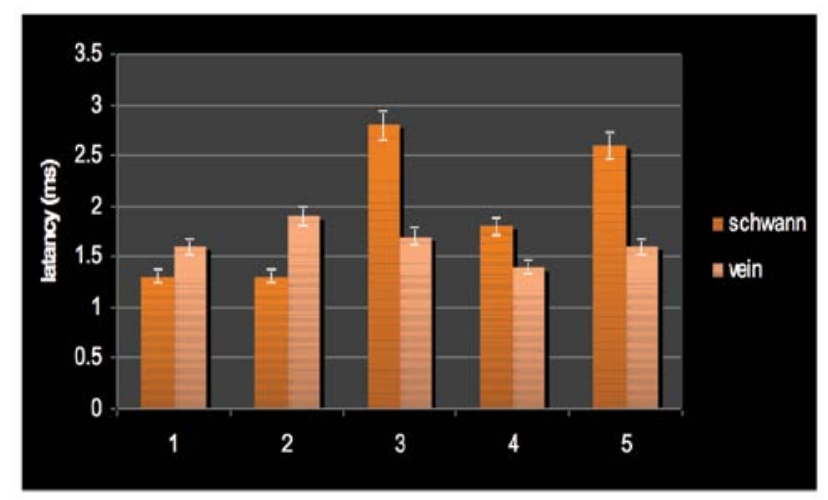

Figure 4: Latency of neural signal after transplantation in individual rats in their respective groups.

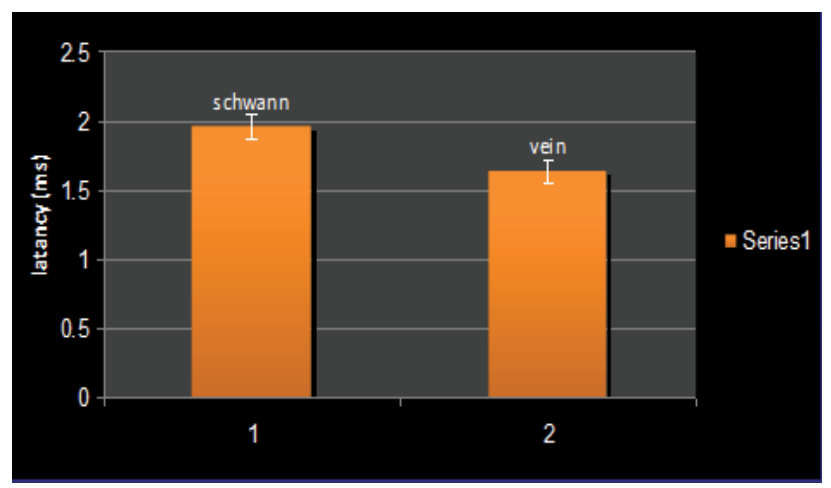

Figure 5: Means of latency in the two groups.

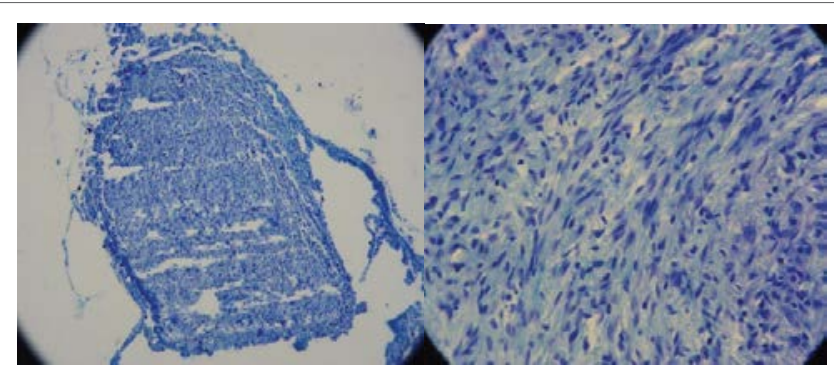

Figure 6: Pathologic view of the distal end of the regenerated sciatic nerve in a rat from the group of SCs transplantation. There is a suitable harmony through the tissue in right side which can explain good signal amplitude.

\section{Discussion}

PNTE has been making a growing body of biomaterials to be used as conduits containing cellular scaffolds for peripheral nerve regeneration. This helps axonal regrowth in shorter periods of time by focusing almost all repair forces into the space provided by the conduit. Veins are still a natural source for use despite new synthetic materials.

Meanwhile, Schwann cells and neurotrophic factors are considered the critical agents in nerve repair. In the current study, role of Schwann cells was evaluated. Schwann cells in the grafted veins can successfully make functional neural tissue. This is not the first time Schwann cells have been used in nerve repair with good results. Some researchers have found that released signals from immune and Schwann cells are definitely necessary for peripheral nerve repair [16-20]. Zarbakhsh, et al. determined Schwann cells to be much more effective than bone marrow stromal cells (BMSCs) in nerve regeneration. They conducted functional evaluation of the grafted rats through electromyography (EMG) and studied their walking and running footprints [21-25]. Schwann cells seem to affect axonal regeneration after establishment of Bungner's bands to direct proximal ends to grow in a well-defined path to achieve distal segments in less time. Although the current study did not focus on a molecular mechanism, it is worth pointing out that some molecular-based studies have been conducted by scientists like Ribeiro, et al. They identified GD3-ganglioside as a regulating factor on the quantity and level of myelination in growing axons. Furthermore, Schwann cell membrane receptors have been shown to be important in their function [26]. Some scientists believe that exercise could be a facilitator in nerve repair especially in regards to obtaining the best functional repair $[26,27]$. Studies on exercise have demonstrated its effects on neurotrophin release $[28,29]$ which in turn, results in better myelination.

\section{Conclusion}

Results from previous studies and the current study provide strong support for autografts with Schwann cells in natural grafts like veins worthy of development in PNS repair. Synthetic materials could also benefit from Schwann cells for transplantation in humans. Limited results obtained in this study demonstrate the need for further studies in the future.

\section{References}

1. Carriel V, Garzón I, Alaminos M, Cornelissen M (2014) Histological assessment in peripheral nerve tissue engineering. Neural Regen Res 9: 1657-1660.

2. Daly W, Yao L, Zeugolis D, Windebank A, Pandit A (2012) A biomaterials approach to peripheral nerve regeneration: bridging the peripheral nerve gap and enhancing functional recovery. J R Soc Interface 9: 202-221.

3. Carriel V, Alaminos M, Garzon I, Campos A, Cornelissen M (2014) Tissue engineering of the peripheral nervous system. Expert Rev Neurother 14: 301-318.

4. Carriel VS, Fernandez-AJ, Santiago-AS, Garzon IJ, Alaminos M, et al. (2011) A novel histochemical method for a simultaneous staining of melanin and collagen fibers. J Histochem Cytochem 59: 270-277.

5. Geuna S, Raimondo S, Ronchi G, Di Scipio F, Tos P, et al. (2009) Histology of the peripheral nerve and changes occurring during nerve regeneration. Int Rev Neurobiol 87: 27-46.

6. Jessen KR, Mirsky R (2008) Negative regulation of myelination: relevance for development, injury, and demyelinating disease. Glia 56: 1552-1565. 
7. Trapp BD, Hauer P, Lemke G (1998) Axonal regulation of myelin protein mRNA levels in actively myelinating Schwann cells. Neurosci 8: 3515-3521.

8. De Felipe C, Hunt S (1994) The differential control of c-jun expression in regenerating sensory neurons and their associated glial cells. $J$ Neurosci 14: 2911-2923.

9. Ceci ML, Mardones KC, Sánchez $M$, Valdivia LE, Allende $M$ (2014) Axon-Schwann cell interactions during peripheral nerve regeneration in zebrafish larvae. Neural Development 9: 22.

10. Farraj AP, Latouche M, Wilton D, Quintes S, Chabrol E, et al. (2012) c-Jun reprograms Schwann cells of injured nerves to generate a repair cell essential for regeneration. Neuron 75: 633-647.

11. Ribeiro RVT, Gomes TA, de Lima S, Lima NM, Rega BM, et al. (2014) Mice Lacking GD3 Synthase Display Morphological Abnormalities in the Sciatic Nerve and Neuronal Disturbances during Peripheral Nerve Regeneration. PLoS ONE 9: e108919.

12. Goulart $\mathrm{CO}$, Jurgensen $\mathrm{S}$, Souto $\mathrm{A}$, Oliveira JT, de Lima $\mathrm{S}$, et al. (2014) A Combination of Schwann-Cell Grafts and Aerobic Exercise Enhances Sciatic Nerve Regeneration. PLoS ONE 9: e110090.

13. Wood MD, Kemp SW, Weber C, Borschel GH, Gordon T (2011) Outcome measures of peripheral nerve regeneration. Ann Anat 193 321-333.

14. Zarbakhsh S, Moradi F, Joghataei MT, Bakhtiari M, Mansouri K, et al. (2013) Evaluation of the Functional Recovery in Sciatic Nerve Injury following the Co-transplantation of Schwann and Bone Marrow Stromal Stem Cells in Rat. Basic Clin Neurosci 4: 291-298.

15. Marinescu SA, Zarnescu O, Mihai IR, Giuglea C, Sinescu RD (2014) An animal model of peripheral nerve regeneration after the application of a collagen-polyvinyl alcohol scaffold and mesenchymal stem cells. Rom J Morphol Embryol 55: 891-903.

16. Mahay D, Terenghi G, Shawcross SG (2008) Schwann cell mediated trophic effects by differentiated mesenchymal stem cells. Exp Cell Res 314: 2692-2701.

17. Wang J, Ding F, Gu Y, Liu J, Gu X (2009) Bone marrow mesenchymal stem cells promote cell proliferation and neurotrophic function of Schwann cells in vitro and in vivo Brain Res 1262: 7-15.

18. Hofstetter CP, Schwarz EJ, Hess D, Widenfalk J, El Manira A, et al. (2002) Marrow stromal cells form guiding strands in the injured spinal cord and promote recovery. Proc Natl Acad Sci USA 99: 21992204.

19. Rosenberg AF, Wolman MA, Armstrong-FC, Granato M (2012) In vivo nerve macrophage interactions following peripheral nerve injury. J Neurosci 32: 3898-3909.

20. Tofaris GK, Patterson PH, Jessen KR, Mirsky R (2002) Denervated Schwann cells attract macrophages by secretion of leukemia inhibitory factor (LIF) and monocyte chemoattractant protein-1 in a process regulated by interleukin-6 and LIF. J Neurosci 22: 66966703.

21. Cui Q, Yin Y, Benowitz LI (2009) The role of macrophages in optic nerve regeneration. Neuroscience 158: 1039-1048.

22. Kyritsis N, Kizil C, Zocher S, Kroehne V, Kaslin J, et al. (2012) Inflammation initiates the regenerative response in the adult zebrafish brain. Science 338: 1353-1356.

23. Monk KR, Talbot WS (2009) Genetic dissection of myelinated axons in zebrafish. Curr Opin Neurobiol 19: 486-490.

24. Zarbakhsh S, Bakhtiari M, Faghihi A, Joghataie MT, Mehdizadeh $M$, et al. (2012) The effects of Schwann and bone marrow stromal stem cells on sciatic nerve injury in rat: A comparison of functional recovery. Cell J 14: 39-46.

25. Silva-B J, Gehlen D, Roman JA, Menta C, Atkinson EA, et al. (2006) Bone marrow stem cells and platelet-rich plasma effects on nervous regeneration and functional recovery in an acute defect model of rats` peripheral nerve. Acta Ortop Bras 14: 273-275.

26. Chen CJ, Ou YC, Liao SL, Chen WY, Chen SY, et al. (2007) Transplantation of bone marrow stromal cells for peripheral nerve repair. Exp. Neurology 204: 443-453.

27. Lu MC, Chang YH, Chiang LC, Wang HT, Cheng CY, et al. (2006) Peripheral nerve regeneration through nerve guides filled with bilobalide and schwann cells. Biomed Eng Appl Basis Comn 18: 8-12.

28. Schlosshauer B, Muller E, Schroder B, Planck H, Muller H (2003) Rat schwann cells in bioresorbable nerve guides to promote, and accelerate axonal regeneration. Brain Res 963: 321-326.

29. Madduri S, Gander B (2010) Schwann cell delivery of neurotrophic factors for peripheral nerve regeneration. J Peripher Nerv Syst 15: 93-103. 